\title{
Alternative approaches to overcome diastasis of damaged peripheral nerves. A review article
}

\author{
Oleg V. Galibin ${ }^{1}$, German V. Medvedev ${ }^{2}$, Pavel V. Popryadukhin ${ }^{3}$, Pavel A. Kulagin ${ }^{1}$, Alexandr A. Gusev ${ }^{1}$, \\ Galina P. Kossyakova ${ }^{1}$, Natalia V. Mikhailova ${ }^{1}$, Veronika D. Novak ${ }^{1}$, Denis N. Solomitskiy ${ }^{1}$, Igor O. Shemiakin ${ }^{1}$, \\ Vadim S. Gadzhiagaev ${ }^{1}$, Maksat Kh. Gurbannazarov ${ }^{1}$ \\ ${ }^{1}$ First St. Petersburg State I. Pavlov Medical University, St. Petersburg, Russia \\ ${ }^{2}$ Russian R. R.Wreden Research Institute of Traumatology and Orthopedy, St. Petersburg, Russia \\ ${ }^{3}$ Institute of Macromolecular Compounds, Russian Academy of Sciences, St. Petersburg, Russia
}

Prof. Dr. Oleg V. Galibin, First St. Petersburg State I. Pavlov Medical University, L. Tostoy St 6-8, 197022, St. Petersburg, Russia
Phone: +7 (981) 7200357

E-mail: ogalibin@mail.ru

Citation: Galibin OV, Medvedev GV, Popryadukhin PV et al. Alternative approaches to overcome diastasis of damaged peripheral nerves. A review article. Cell Ther Transplant 2019; 8(1): 20-25.

\section{Summary}

Damage of peripheral nerves is often accompanied by a primary or secondary diastasis (gap, spread) between the neural ends, thus complicating a standard manual nerve stitching by means of surgical threads. As based on analysis of published data, the effective techniques were proposed for surgical treatment of peripheral nerve damage accompanied by diastasis. Moreover, some limitations of autoneural plastics are clearly revealed. Therefore, overcoming of nerve diastasis following damage remains to be a strong need, especially when treating prolonged and multiple defects of nerve trunks. Usage of implants providing repair and junction of the dam- aged nerve seems to be an alternative option allowing end-to-end connection of the damaged nerve from its central to distal segment. Application of biocompatible and bio-degradable polymers as a neural prosthesis promotes more safe regeneration and does not require switching-off a donor nerve and its functions. Moreover, the options are improved which allow to influence rates and quality of the nerve damage repair.

\section{Keywords}

Nerve, damage, diastasis, implant, polymeric scaffolds, chitosan.

\section{Introduction}

Autologous nerve transplantation still remains a golden standard for reconstruction of peripheral nerves. Autologous sural nerve is mostly often harvested and transplanted into the gap dividing two ends of the damaged nerve. The main problem of this approach occurs due to the area of the nerve harvesting which may be associated with its functional loss and risk of painful neurinoma. Moreover, the material for grafting is available only in limited amounts. Hence, full reconstruction seems to be impossible, especially in extensive nerve lesions (i.e., of brachial plexus) [1].
This problem may be resolved by means of an implant (conduit) allowing to join the ends of damaged nerve, thus promoting invasion of nervous fibers from its central segment to peripheral part. Different materials were proposed for implantation that may be classified into distinct groups, i.e., biological implants (veins, skeletal muscles) $[2,3]$, or synthetic materials. Moreover, the synthetic conduits may be resorbable, such as chitosan conduit, polylactide tubule, conduits of biodegradable polyurethane, neurotube of polyglycolic acid), and non-resorbable implants, e.g., silicon tubes [1]. Therefore, we present a review of literature on the surgery of peripheral nerves ruptures with diastasis. We have collected the data of efficiency of different methods used for overcoming diastasis of the injured peripheral nerves. 


\section{Biological implant materials}

Usage of venous grafts in order to overlap a gap between the ends of damaged nerve shows some benefits including simple access, minor associated injury during the vein harvest, wide choice of veins with different-diameters. Moreover, the venous wall is permeable for the nutrients; basal lamina of veins is enriched with laminin, thus improving nerve regeneration, whereas the venous matter is a non-immunogenic substance $[2,3]$.

Meanwhile, Guerra et al. [2] have shown that the empty venous graft tends for collapse. Therefore, it is reasonable to fill the conduit with different substances in order to provide its structural properties and improve the nerve regeneration processes [2].

\section{Synthetic materials}

An ideal material for a synthetic conduit should meet the following requirements: biocompatibility, structural and mechanical properties corresponding to natural nervous tissue, appropriate biodegradation rates that should provide structural support during the entire regeneration period, however, without a risk of nerve compression. The biodegradation products should be non-toxic and optimal porosity of this material should be of 70-98\%; It should be hard and flexible $[4,5]$.

Over last years, a number of workers have proposed different synthetic biodegradable materials meeting these criteria, i.e., chitosan, polylactide, their derivates, as well as electroconductive polymers.

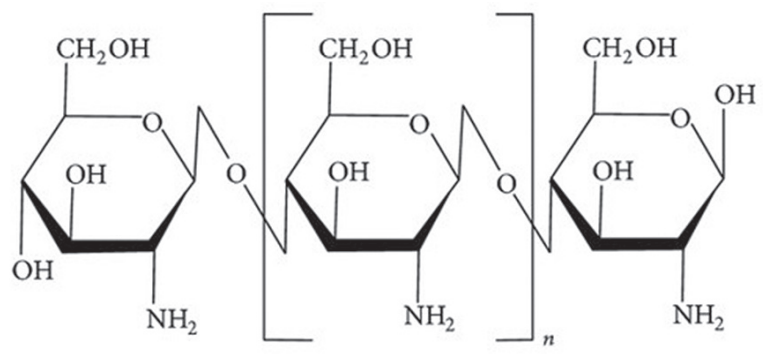

\section{Figure 1. Chitosan structure [4]}

Chitosan is a derivative obtained by alkaline deacelylation of the chitin polymer (Fig. 1). I.e., the deacetylation degree in chitosan is a key characteristic which determines its physical, chemical and biological features. This parameter sufficiently determines the rates of the polymer degradation, due to controlled deacetylation processes during chitosan preparation (the chitosan degradation rate is reversely proportional to the polymer crystallinity and, therefore, to its decatylation degree). Moreover, the regulated porosity of the chitosan scaffolds ( 80 to $90 \%$, with the pore size of 50 to 250 $\mathrm{mcm}$ ) is faforable to angiogenesis which plays a fundamental role in survival and functioning of regenerated nerve fibres. Chitosan is depolymerized in the tissues by means of enzymatic hydrolysis mediated by different hydrolases including lysozyme, pectinases, cellulases, hemicellulases, lipases and amylases. The chitin degradation results into oligosaccharides and monosaccharides, netural metabolites of glucosaminoglycanes, or glucoaminoproteins [4].
Due to all these characteristics, chitosan is considered plausible material for usage in the nerve tubulization. When performing comparative evaluation of axon repair after the defect reconstruction by hollow chitosan conduits of different acetylation degrees, donor nerve autograft, and silicon tube, the best results were obtained in the "golden standard" group. The least efficiency was documented with the silicon conduits. Moreover, they have revealed better regeneration with chitosan acetylated for $5 \%$, than with $2 \%$ acetyl groups [7].

The results comparable with autoneural inserts could be achieved by endoneurium modeling due to supplement of a hollow chitosan conduit by the biologically active filler medium consisting of stabilized collagen and enriched by fibronectin [8].

Addition of pro-regenerative cells (Schwann, mesenchimal cells) to the mentioned enriched scaffold restores a natural nerve environment which could be provided by autotransplant. Some workers (Gonzalez-Perez et al.) report on 100\% success in nerve regeneration when using the given method with Schwann cell supplementation. E.g., usage of the scaffolds the scaffolds enriched by mesenchymal cells and extracellular matrix substances is associated with $90 \%$ success in nerve repair, whereas hollow chitosan tubes bring about $75 \%$ success rates [9].

Hence, a combination of chitosan conduits with enriched extracellular matrix and pro-regeneration cells represents a good alternative to the usage of autotransplants in order to restore longitudinal gaps after the nerve injury $[8,9]$.

A number of other works described chitosan applications combined with other substances, both as conduit, or filling medium (Table 1) [11]. The authors report on good results of nerve regeneration when using tubulization with composite polymeric grafts based on chitosan with polyglycols [10]. Wang et al. [10] did not reveal any statistically significant differences in nerve recovery when testing the mentioned polymeric tubes and "gloden standard".

Otherwise, the chitosan conduits have shown good results when applying them for restoration of the human nerve integrity (Fan et al.) [12].

\section{Polylactide}

Polylactide is a biodegradable thermoplastic polyesther. Polylactide was used as a hollow tibe as a conduit for the nerve reconstruction, as well as a component of composite polymers combined with polycaprolactone or polyglycolide. Polylactide tube was superior to polycaprolactone scaffold, having been compatible with autoneural transplant by its efficiency [13].

Copolyesther-based conduits comprising combinations of polylactide and polycaprolactone, (Neurolac1), and those based on a combination of polylactide and polyglycolide (PLGA) did not show statistically significant differences against the model with autologous donor nerve. However, the polyesther-based scaffolds exhibited a longer biodegradation period as compared with PLGA scaffolds (16-20 and 12 weeks, respectively). Moreover, the biodegradation rate for PLGA conduites correlates with its monomeric compo- 
sition (i.e., the glycolic-to-lactic acid ratio). The authors also note that degradation products of this polymer show acid reaction, thus leading to decreased tissue $\mathrm{pH}$ and development of immune response. Co-polyester provides lesser amounts of acid products upon its biodegradation. PLGA, however, has a benefit due to its microporosity [14].
Some authors reported on better recovery nerve functions when using the co-polyesther when compared to the approved "golden standard" $[15,16]$.

Moreover, some studies dealt with abovementioned hollow polymeric tubes combined with different filling media (Table $2,3)[11]$

Table 1. Results of chitosan application combined with other substances and polymers [11]

\begin{tabular}{|c|c|c|c|c|c|c|}
\hline Year & Material & Nerve & Gap (mm) & Animal & Resultados & Ref \\
\hline 2004 & Chitosan-chitin powder & Sciatic & 8 & Rat & Compatible with the surround tissue in vivo & [79] \\
\hline 2005 & Chitosan-neurosteroids & Facial & 10 & Rabbit & $\begin{array}{l}\text { Regeneration of the nerve fibers. Faster regeneration when } \\
\text { using the neurosteroids in vivo }\end{array}$ & [80] \\
\hline 2005 & $\begin{array}{l}\text { Chitosan-Filaments } \\
\text { of PGA }\end{array}$ & Sciatic & 30 & Dog & Restoration of nerve continuity and functional recovery & [39] \\
\hline 2009 & Chitosan-GDNF & Sciatic & 10 & Rat & Axon area and myelination higher than chitosan tube (control) & [69] \\
\hline 2010 & $\begin{array}{l}\text { Cross-linked carboxy- } \\
\text { methyl chitosan }\end{array}$ & Sciatic & 10 & Rat & $\begin{array}{l}\text { Myelin sheath similar to nerve autografts and higher fiber } \\
\text { density compared to chitosan tube }\end{array}$ & [70] \\
\hline 2013 & $\begin{array}{l}\text { Chitosan with varying } \\
\text { degrees of acetylation }\end{array}$ & Sciatic & 10 & Rat & Poor mechanical properties and low stability & [73] \\
\hline 2013 & $\begin{array}{l}\text { Collagen-Chitosan with } \\
\text { RGD }\end{array}$ & Sciatic & 15 & Rat & $\begin{array}{l}\text { Faster regeneration with RGD compared with } \\
\text { collagen-chitosan tubes }\end{array}$ & [81] \\
\hline 2015 & Chitosan & Phrenic & 15 & Dog & Functional recovery was not totally achieved & [82] \\
\hline
\end{tabular}

Table 2. Studies with PLGA-based conduites with different filling substances [11]

\begin{tabular}{|c|c|c|c|c|c|c|}
\hline Year & Material & Nerve & Gap (mm) & Animal & Results & Ref \\
\hline 2004 & PLGA(85:15)+Schwann cells & sciatic & 10 & rat & $\begin{array}{l}\text { Ultrasonic stimulation has a positive effect on seeded Schwann } \\
\text { cells within PLGA conduit }\end{array}$ & [126] \\
\hline 2006 & $\operatorname{PLGA}(85: 15)$ & sciatic & 10 & rat & Asymmetric structure enhance the removal of drained waste & [127] \\
\hline 2007 & PLGA (90:10; 50:50)+Schwann cells & sciatic & 10 & rat & $\begin{array}{l}\text { Directional permeability has a positive effect in nerve } \\
\text { regeneration through PLGA conduits }\end{array}$ & [5] \\
\hline 2007 & PLGA (90:10) & sciatic & 10 & rat & Axon regeneration similar to Neurolac & [128] \\
\hline 2008 & PLGA/Pluronic F127 & sciatic & 10 & rat & $\begin{array}{l}\text { Regeneration achieved due to good mechanical properties, } \\
\text { permeability and prevention of scar tissue invasion }\end{array}$ & [129] \\
\hline 2010 & PLGA/Chitosan+CNTF & tibial & 25 & dog & Favorable conduit for Schwann cell migration and axonal regeneration & [130] \\
\hline
\end{tabular}

Table 3. Conduites based on caprolactone with different fillers [11]

\begin{tabular}{|c|c|c|c|c|c|c|}
\hline Year & Material & Nerve & Gap (mm) & Animal & Results & Ref \\
\hline 2012 & $\mathrm{PCL}+\mathrm{MSCs}$ & sciatic & 3 & rat & Gastrocnemius muscle was restored while motor function was improved. & [134] \\
\hline 2013 & PCL/Pluronic F127 & sciatic & 10 & rat & $\begin{array}{l}\text { The double stimulation of nerve growth factor (NGF) and low-intensity pulse ultrasound } \\
\text { (US) were more effective in nerve regeneration than single stimulation. }\end{array}$ & [137] \\
\hline 2014 & $\begin{array}{l}\mathrm{PCL} / \text { gelatin+stem } \\
\text { cells (SHED) }\end{array}$ & sciatic & 10 & rat & Improved nerve regrowth across the SHED seeded conduit. & [138] \\
\hline 2014 & $\mathrm{PCL} /$ gelatin & sciatic & 5 & rat & $\begin{array}{l}\text { Electrospun PCL is more suitable for in vivo implantation than PCL/gelatin } \\
\text { due to poor histology and electrophysiology. }\end{array}$ & [139] \\
\hline 2014 & $\mathrm{PCL}+\mathrm{Schwann}$ cells & sciatic & 14 & rat & Electrospun bilayered seeded conduits improve the sprouting of nerve fibers and motor recovery. & [140] \\
\hline
\end{tabular}




\section{Electroconductive polymers}

Due to limited nerve regeneration capacity, their reconstitution often requires different biological factors which may control cellular metabolic activity including cell adhesion, differentiation and cytokine secretion. Electric signals are among such factors [17]. Therefore, development of a biodegradable scaffold able to conduct electricity was an important challenge to the workers.

A need for electroconductive polymers was initiated by a study which led to a 10-million-fold increase of polyacetylene conductivity by means of oxydation in iodine vapor. (Normally, polyacethylene is a semi-conductor). This modification, called doping, is the major condition for acquiring the polymer conductivity. The doping process proceeds during the polymer synthesis, or it may be performed by chemical, electrochemical methods, or by means of photo-doping. Moreover, this process may proceed in two ways: $\mathrm{p}$-doping with polymer oxidation and getting the positive charge; and n-doping with polymer reduction and its negative charging. In brief, the polymer (semi-conductor, insulator) is supplied with small amounts of an additive agent which removes or adds an electron to the polymeric chain which eliminates or adds an electron to the polymer chain, this resulting into a delocalized electric charge (Fig. 2, A) [18]. Thereafter, a localization of the charge by a point distorsion of a crystal grid, i.e., the polaron formation (Fig. 2, B, C) [18]. Polaron is able to migrate along the polymer chain, thus allowing it to conduct electricity (Fig. 2, D) [18].

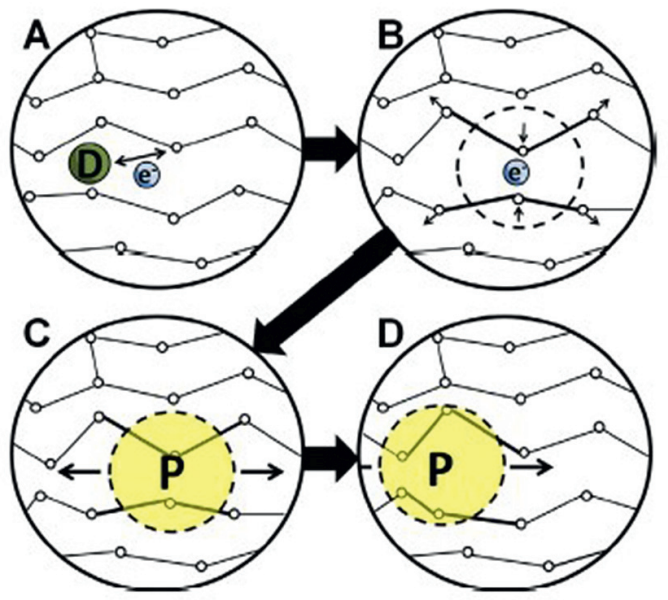

Figure 2. Simplified description of electroconductivity for conducting polymers: (A) removal or addition of an electron to the polymer chain using a doping additive, thus leading to formation of a delocalized charge; $(B, C)$, the charge localization and its surrounding by a local distortion of crystal grid (polaron formation); (D), polaron migration along the polymer chain, thus providing electric conductivity [18]

Polypyrrole is the most studied electroconductive polymer. Chen et al. [19] have used a polypyrrole tube for reconstitution of injured N.ischiadicus in rats. As a result, the authors have revealed that the given polymer is biocompatible and suitable for the nerve electrostimulation procedures [19].
A derivative of polytiophen (PEDOT) is also a promising electroconductive polymer for applications in the nerve regeneration, due to its biocompatibility, electroconductivity and higher electric stability than in polypyrrols. Moreover, carboxymethylchitosan (CMCS), a composite electroconductive polymer was also developed and used. CMSC served as the main macromolecular network able for biodegradation, whereas poly-3,4-ethylenedioxythophen (PEDOT) was applied as a conductive polymeric layer. Herewith, the samples of such polymer show maximal electric conductivity at the polyethylenedioxythophen concentration of $0.2 \mathrm{M}$. Worth of note, this composite scaffold dose not exert any toxic effect upon the cells, and, alternatively, supports their adhesion survival and proliferation [20]. These characteristics make it an appropriate material for designing a scaffold for the nerve regeneration.

Therefore, usage of the nerve tubulization techniques with biodegradable polymeric conduits is mostly showing a statistically and clinically significant regeneration efficiency which is comparable with autoneural insertion. Upon the conduit functionalization by a biologically active medium and pro-regeneratory cells, one may achieve even better results than with autologous transplants $[2,8,9,10,12,13,14]$. Additionally, this approach may avoid some problems with harvesting of donors' nerve which occur in autotransplantation method, the approved "golden standard" $[1,5,7,11]$.

Moreover, when developing electroconductive polymeric scaffolds, one may combine the benefits of biodegradable polymers with electroconductivity, as a factor enabling nerve cell differentiation, enhance neurite growth and peripheral nerve regeneration. Therefore, this mode of bioengineering is quite promising for usage in the surgery of peripheral nerves, thus requiring further studies in the field [17-20].

\section{Conclusion}

Injury of peripheral nerves is often accomplished by a sufficient diastasis (gap) between the ends of damaged nerve, thus making it difficult to perform a standard manual suture using surgical threads. As based on analysis of published data, some effective methods are proposed for surgical treatment of peripheral nerve injuries with diastasis. Moreover, some problems of autoneural plastics are revealed. Thus, the aspects of overcoming such diastasis remain to be timely, especially in cases of longitudinal and multiple nerve defects. An alternative option in resolving such problems is offered, i.e., usage of implants allowing to connect the ends of a damaged nerve and promoting invasion of neural fibres from the central to peripheral processus of the damaged nerve. Usage of biocompatible and biodegradable polymers as a neural prosthesis promotes a more safe regeneration, and does not require switching off the donor nerve and its function. Moreover, some new options allow to influence regeneration rates and quality of the damaged peripheral nerves. As shown by the mentioned data, one may state that application of the proposed methods in many observations brings about statistically and clinically significant results that may objectively compete with results of autoneural grafting. Hence, further studies of the tubulization method open a prospective in surgical treatment of damaged peripheral nerves with 
diastasis. Therefore, further studies in tubulization method is a promising direction in this field, providing a serious potential for successful reconstructive surgical interventions.

\section{Conflict of interests}

None of the authors report any conflicts of interest.

\section{References}

1. Comparative neuro tissue engineering using different nerve guide implants / N. Sinis, H.-E. Schaller, C. Schulte-Eversum, T. Lanaras, B. Schlosshauer, M. Doser, K. Dietz, H. Rosner, H.-W. Muller, M. Haerle. Acta Neurochir (Suppl). 2007 100: 61-64.

2. Sabongi RG, Fernandes M, Dos Santos JB. Peripheral nerve regeneration with conduits: use of vein tubes. Neur Regener Res. 2015;10(4):529-533.

3. Bueno CRS, Pereira M, Aparecido I Favaretto-Júnior, Buchaim RL, Andreo JC, Rodrigues AC, Marco G Rosa-Júnior. Comparative study between standard and inside-out vein graft techniques on sciatic nerve repair of rats. Muscular and functional analysis. Acta Cir Bras. 2017;32(3):287-296.

4. Yao K, Li J, Yao F, Yin Y. Chitosan-based hydrogels: functions and applications. 2012 by Taylor \& Francis Group, LLC: 408-409.

5. Bauback S, Buncke G. Autograft substitutes conduits and processed nerve allografts. Hand Clin. 2016; 32: 127-140.

6. Kuffler DP. Promoting axon regeneration and neurological recovery following traumatic peripheral nerve injuries. Int J Neurorehabilitation. 2015, 2:1.

7. Gonzalez-Perez F, Cobianchi S, Geuna S, Barwig C, Freier T., Udina E, Navarro X. Tubulization with chitosan guides for the repair of long gap peripheral nerve injury in the rat. Microsurgery. 2015;35(4):300-308.

8. Gonzalez-Perez F, Cobianchi S, Heimann C, Phillips JB, Udina E, Navarro X. Stabilization, rolling, and addition of other extracellular matrix proteins to collagen hydrogels improve regeneration in chitosan guides for long peripheral nerve gaps in rats. Neurosurgery. 2017; 80(3):465-474.

9. Gonzalez-Perez F, Hernández J, Heimann C, Phillips JB, Udina E, Navarro X. Schwann cells and mesenchymal stem cells in laminin- or fibronectin-aligned matrices and regeneration across a critical size defect of $15 \mathrm{~mm}$ in the rat sciatic nerve. J Neurosurg Spine 2017; 28(1): 109-118.

10. Wang X, Hu W, Cao Y, Yao J, Wu J, Gu X. Dog sciatic nerve regeneration across a $30-\mathrm{mm}$ defect bridged by a chitosan/PGA artificial nerve graft Brain. 2005; 128(8): 18971910.

11. Pinho AC, Fonseca AC, Serra AC, Santos JD, Coelho JF. Peripheral nerve regeneration: current status and new strategies using polymeric materials. Adv Healthc Mater. 2016; 5(21): 2732-2744.

12. Fan W, Gu J, Hu W, Deng A, Ma Y, Liu J, Ding F, Gu $\mathrm{X}$. Repairing a 35-mm-long median nerve defect with a chi-
tosan/PGA artificial nerve graft in the human: a case study. Microsurgery. 2008; 28(4):238-242.

13. Goulart CO, Lopes FR, Monte ZO, Dantas SV Jr, Souto A, Oliveira JT, Almeida FM, Tonda-Turo C, Pereira CC, Borges CP, Martinez AM. Evaluation of biodegradable polymer conduits - poly (L-lactic acid) - for guiding sciatic nerve regeneration in mice. Methods. 2015; 99:28-36.

14. Luis AL, Rodrigues JM, Amado S, Veloso AP, Armada-Da-Silva PA, Raimondo S, Fregnan F, Ferreira AJ, Lopes MA, Santos JD, Geuna S, Varejão AS, Maurício AC. PLGA $90 / 10$ and caprolactone biodegradable nerve guides for the reconstruction of the rat sciatic nerve. Microsurgery. 2007; 27(2):125-137.

15. Den Dunnen WFA, Van der Lei B, Schakenraad JM, Stokroos I, Blaauw E, Bartels H, Pennings AJ, Robinson $\mathrm{PH}$. Poly(DL-lactide-e-caprolactone) nerve guides perform better than autologous nerve grafts. Microsurgery 1996; 17: 348-357.

16. den Dunnen WF, van der Lei B, Robinson PH, Holwerda A, Pennings AJ, Schakenraad JM. Biological performance of a degradable poly (lactic acid-epsilon-caprolactone) nerve guide: Influence of tube dimensions. J Biomed Mater Res. 1995; 29(6): 757-766.

17. Song S, George PM. Conductive polymer scaffolds to improve neural recovery. Neural Regen Res.2017; 12(12):19761978.

18. Balint R, Cassidy NJ, Cartmell SH. Conductive polymers: towards a smart biomaterial for tissue engineering. Acta Biomater. 2014;10(6):2341-2353.

19. Kabiri M, Oraee-Yazdani S, Dodel M, Hanaee-Ahvaz H, Soudi S, Seyedjafari E, Salehi M, Soleimani M. Cytocompatibility of a conductive nanofibrous carbon nanotube/poly (l-lactic acid) composite scaffold intended for nerve tissue engineering. EXCLI J. 2015;14:851-860.

20. Xu C, Guan S, Wang S, Gong W, Liu T, Ma X, Sun C. Biodegradable and electroconductive poly(3,4-ethylenedioxythiophene)/ carboxymethyl chitosan hydrogels for neural tissue engineering. Mater Sci Eng C Mater Biol Appl. 2018;84:32-43 


\section{Альтернативные методы преодоления диастаза поврежденного периферического нерва (обзор литературы)}

Олег В. Галибин ${ }^{1}$, Герман В. Медведев ${ }^{2}$, Павел В. Попрядухин ${ }^{3}$, Павел А. Кулагин ${ }^{1}$, Александр А. Гусев ${ }^{1}$,

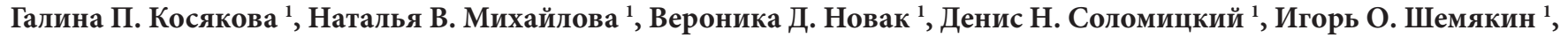
Вадим С. Гаджиагаев ${ }^{1}$, Максат Х. Гурбанназаров ${ }^{1}$

${ }^{1}$ Первый Санкт-Петербургский государственный медицинский университет им. акад. И. П. Павлова

${ }^{2}$ Российский НИИ травматологии и ортопедии им. Р. Р. Вредена, Санкт-Петербург, Россия

${ }^{3}$ Институт высокомолекулярных соединений РАН, Санкт-Петербург, Россия

\section{Резюме}

Повреждение периферических нервов нередко сопровождается значительным диастазом (первичным или вторичным) между концами поврежденного нерва, что затрудняет выполнение стандартного ручного шва нерва с помощью хирургических нитей. На основании анализа данных опубликованных исследований выявлены эффективные способы хирургического лечения повреждений периферических нервов с диастазом. Кроме того, достоверно выявлены недостатки метода аутоневральной пластики, в связи с чем проблема преодоления диастаза поврежденного периферического нерва остается актуальной и в настоящее время, особенно при протяженных и множественных дефектах нервных стволов. Альтернативным вариантом в решении данной проблемы может служит использование имплантов, позволяющих соединить концы поврежденного нерва и способствующих прорастанию нервных волокон из центрального в периферический отросток поврежденного нерва. Использование биосовместимых и биодеградируемых полимеров в качестве неврального протеза способствует более безопасной регенерации и не требует выключения донорского нерва и связанной с ним функции, кроме того, разработаны и продолжают совершенствоваться опции, позволяющие влиять на скорость и качество регенерации поврежденного периферического нерва.

\section{Ключевые слова}

Нерв, травма, диастаз, имплант, полимерная основа, хитозан. 